\title{
Cleft Maxilla
}

National Cancer Institute

\section{Source}

National Cancer Institute. Cleft Maxilla. NCI Thesaurus. Code C124513.

A cong enital abnormality consisting of a fissure in the midline of the upper jawbone. 